\title{
PERBANDINGAN HASIL REFRAKSI SUBJEKTIF PADA JARAK 6 METER DAN 4 METER MENGGUNAKAN SLIDE PROJECTOR
}

\author{
Anggit Nugroho'), Avita Ferens Ferdinandus ${ }^{2)}$ \\ 1) PMN RS Mata Cicendo Bandung Indonesia \\ 2)Program Studi Diploma Tiga Refraksi Optisi STIKes Dharma Husada \\ ${ }^{1}$ raffa.refraksionis@gmail.com \\ f.avita@yahoo.com
}

\begin{abstract}
ABSTRAK
Pemeriksaan refraksi didentifikasikan sebagai pengukuran terhadap gangguan refraksi. Pemeriksaan refraksi dibagi menjadi 2 yaitu pemeriksaan refraksi objektif dan subjektif. Pemeriksaan refraksi subjektif merupakan pemeriksaan yang bergantung pada kerjasama pasien dalam menilai perbaikan refraksi selama pemeriksaan. Pemeriksaan refraksi subjektif jarak jauh pada umumnya menggunakan snellen chart dengan jarak 6 meter. Pada kunjungan penulis, ditemukan tempat pemeriksaan yang kurang dari 4 meter menggunakan snellen chart. Sehingga dalam penelitian ini penulis bertujuan untuk membandingkan hasil refraksi subjektif pada 6 meter dan 4 meter dengan metode yang digunakan adalah cross sectional. Hasil penelitian menunjukkan bahwa ada perbedaan antara hasil refraksi subjektif pada jarak 6 meter dan 4 meter sebanyak 97 mata dari 104 mata yang diteliti.
\end{abstract}

Kata Kunci : Pemeriksaan refraksi subjektif, Pemeriksaan refraksi objektif, snellen chart, slide proyector

\begin{abstract}
Refraction examination is identified as a measurement of refractive disorders. Refraction examination is divided into 2, namely objective and subjective refraction examinations. A subjective refraction examination is an examination that depends on the collaboration of the patient in assessing refraction the examination. Long distance subjective refraction checks generally use snellen chart at a distance of 6 meters. On the author's visit, it was found a checkpoint that was less than 4 meters using the snellen chart. Therefore, in this study the author aims to compare the results of subjective refraction at 6 meters and 4 meters with the method used cross sectional. The results showed that there were differences between the results subjective of refraction at a distance of 6 meters and 4 meters by 97 eyes from 104 eyes studied.
\end{abstract}

Keywords: Refraction examination subjective, Refraction examination objective, snellen chart, slide proyector

\section{PENDAHULUAN}

Organ Penglihatan (mata) merupakan salah satu panca indra dengan fungsi melihat dengan tajam apabila pancaran cahaya dari suatu obyek jatuh tepat di titik fokus saraf mata atau yang dikenal dengan retina. Bagian mata yang disebut pupil akan berfungsi sebagai "jendela" mengatur jumlah cahaya yang masuk kedalam mata, yang kemudian akan difokuskan oleh lensa kristalin dan diteruskan ke sentral penglihatan retina.

Kelainan refraksi dapat diketahui dengan adanya pemeriksaan refraksi. Pemeriksaan refraksi diidentifikasikan sebagai pengukuran 
terhadap gangguan refraksi yang merupakan penerapan klinis dan prinsip optik oleh seorang pemeriksa dengan menggunakan instrument sederhana hingga menggunakan alat yang canggih. Pemeriksaan refraksi juga merupakan pemeriksaan yang paling mendasar dalam menentukan kelainan mata serta terapi yang dibutuhkan juga untuk menentukan penyebab pasien mengeluh penurunan fungsi penglihatan, yang berasal dari gangguan refraksi atau kelainan organik. (PMN RS Mata Cicendo, 2018).

Pemeriksaan refraksi dibagi menjadi 2 kategori yaitu pemeriksaan objektif dan subjektif. Pemeriksaan objektif dilakukan hanya menggunakan alat untuk menentukan status refraksi pasien. Keuntungan pemeriksaan ini adalah tidak adanya ketergantungan kepada pasien untuk memberikan jawaban dan hasil dapat diperoleh dalam waktu singkat. Sedangkan pemeriksaan refraksi subjektif bergantung pada kerjasama pasien dalam menilai perbaikan refraksi selama pemeriksaan, tetapi memberikan hasil yang baik dan akurat untuk dijadikan dasar pengambilan keputusan terapi. (PMN RS Mata Cicendo, 2018).

Pada saat pemeriksaan refraksi subjektif kontrol akomodasi adalah elemen terpenting. Akomodasi merupakan suatu mekanisme dimana mata merubah kekuatan refraksinya dengan merubah ketajaman lensa kristalin. Daya akomodasi dibatasi oleh dua titik yaitu titik dekat (punctum proximum) dan titik jauh (punctum remotum). (Rinda Wati, 2018).

Jika mata berakomodasi pada benda jauh tak terhingga yang didekatkan, maka otot-otot siliar akan menjadi tegang yang dapat mengakibatkan kelelahan mata, sedangkan titik jauh didefinisikan sebagai titik terkonjugasi dengan retina tanpa adanya akomodasi yang diinginkan dari prosedur subjektif. (Mark Rosenfield, 2014, hal. 210).

Umumnya pemeriksaan refraksi subjektif jarak jauh menggunakan objek yaitu huruf snellen yang ada pada snellen chart atau slide proyector dengan jarak 20 kaki atau 6 meter. Jarak Pengujian actual perlu diperhitungkan secara akurat. Dalam pemeriksaan refraksi, jarak yang lebih pendek tidak disarankan, menggunakan snellen dalam jarak 4 meter terdapat sisa akomodasi $0.25 \mathrm{D}$ dan tidak dapat diabaikan. Jika pemeriksaan dilakukan pada jarak 4 meter, biasanya digunakan dalam pemeriksaan menggunakan \ETDRS Chart. (Precision vision, 2019).

Studi pendahuluan terkait tingkat pengetahuan refraksi optisi tentang dampak jarak pemeriksaan refraksi yang tidak standard terhadap hasil koreksi di optik melawai Bandung dengan 20 Responden menyatakan $58 \%$ refraksi optisi mengetahui adanya dampak jarak pemeriksaan terhadap hasil koreksi.

Penelitian ini bertujuan untuk mengetahui perbedaan hasil refraksi subjektf pada jarak 6 meter dan jarak 4 meter menggunakan slide projector. Sehingga diharapakan dapat 
JURNAL SEHAT MASADA VOLUME XV

dijadikan informasi dan pengetahuan mengenai perbedaan hasil koreksi refraksi subjektif pada jarak 4 meter dan 6 meter

\section{METODOLOGI PENELITIAN}

Penelitian ini betujuan untuk mengetahui perbandingan hasil refraksi subjektif pada jarak 6 meter dan 4 meter menggunakan slide projector. Penelitian ini termasuk jenis penelitian komperatif, yaitu penelitian yang dilakukan dengan cara membandingan persamaan dan perbedaan sebagai fenomena untuk mencari faktor-faktor apa, atau situasi bagaimana yang menyebabkan timbulnya suatu peristiwa tersebut.

Waktu oengumpulan data menggunakan pendekatan Cross Sectional yaitu untuk mendapatkan sebuah sempel dari populasi dalam suatu waktu, yang artinya setiap subjek penelitian hanya diobservasi sekali saja dan pengukuran dilakukan terhadap status karakter atau variabel subjek pada pemeriksaan.

Populasi pada penelitian ini adalah seluruh mahasiswa D3 Refraksi Optisi tingkat 1 dan 2 kelas reguler angkatan 2017 dan 2018 STIKes Dharma Husada Bandung yang berjumlah 80 orang. Penentuan sampel penelitian sesuai dengan syarat inklusi dan eksklusi. Syarat inklusi dalam penelitian ini yaitu mahasiswa dengan kondisi emetropia dan ametropia, dan syarat ekslusi yaitu mahasiswa dengan kelainan penglihatan seperti ambliopia. Sampel pada penelitian ini merupakan responden dengan inklusi emetropia dan ametropia yaitu mahasiswa prodi D3 Refraksi Optisi tingkat 1 dan 2 dengan total 79 orang, dan dalam melaksanakan penelitian yang bersedia menjadi responden/subjek penelitian berjumlah 52 orang.

Dalam penelitian ini, penulis menggunakan data primer yang diperoleh dari pengumpulan data secara langsung. Data didapatkan dari hasil pemeriksaan refraksi subjektif pada jarak 6 meter dan jarak 4 meter menggunakan slide projector. Dalam pengumpulan data, peneliti dibantu 4 orang pengumpul data yang sbeelumnya telah diberi penjelasan sesuai pedoman penelitian. Dalam pengambilan data ini, 1 subjek penelitian diperiksa pada jarak 6 meter dan 4 meter oleh pemeriksa yang berbeda.

a. Pemeriksaan Refraksi Subjektif menggunakan jarak 6 meter

1) Pemeriksaan dilakukan pada Lab. Refraksi Optisi dengan ruang yang semi gelap (cahaya buatan tidak digunakan kecuali cahaya pada projector)

2) Mengatur Jarak pemeriksaan : objek pemeriksaan (slide projector) dijauhkan 6 meter dari posisi duduk pasien

3) Melakukan pemeriksaan refraksi :

a) Menentukan BVS (Best Visus Sphere)

b) Menentukan Astigmat

c) Menentukan Titik akhir monokuler

d) Menguji keseimbangan binokuler

e) Menentukan Titik akhir binokuler

b.Pemeriksaan Refraksi Subjektif menggunakan jarak 4 meter 
1) Pemeriksaan dilakukan pada Lab. Refraksi Optisi dengan ruang yang semi gelap (cahaya buatan tidak digunakan kecuali cahaya pada projector)

2) Mengatur Jarak pemeriksaan : objek pemeriksaan (slide projector) dijauhkan 4 meter dari posisi duduk pasien

3) Mengatur Fokus Projector agar huruf yang ditampilkan lebih jelas

4) Melakukan pemeriksaan refraksi : a)Menentukan BVS (Best Visus Sphere)

b)Menentukan Astigmat

c)Menentukan Titik akhir monokuler

d)Menguji keseimbangan binokuler

e)Menentukan Titik akhir binokuler

Teknik pengolahan data melalui tahapan :

a. Editing (Penyunting) Sebelum data diolah untuk mendapatkan hasil penelitian ini, data yang diperoleh harus melalui penyuntingan terlebih dahulu. Penyuntingan sendiri merupakan proses dimana penulis melakukan klarifikasi, kosistensi, dan kelengkapan data yang sudah terkumpul.

b. Coding (Pengkodean), untuk menghitung jumlah adanya perbedaan dan persamaan nantinya serta karakteristik penelitian. Kode yang digunakan dalam penelitian ini antara lain :

$$
\begin{aligned}
& \mathrm{F}=\text { Female/ Perempuan } \\
& \mathrm{M}=\text { Male/ Laki }- \text { laki } \\
& \mathrm{R}=\text { Right (kanan) } \\
& \mathrm{L}=\text { Left (Kiri) } \\
& \mathrm{S}=\text { Spheris } \\
& \mathrm{C}=\text { Cylinder }
\end{aligned}
$$

$\mathrm{Ax}=$ Axis

$1=$ Menyatakan perbedaan

$0=$ Menyatakan Persamaan

c. Entry (Pemasukan)/ processing, yaitu memasukan data berbentuk kode angka/huruf kedalam program atau software komputer pengolah data. Dilakukan dengan pengolah data Ms. Excel, dan untuk uji perbedaan secara signifikan, data akan dimasukan kedalam aplikasi SPSS 16.0. Untuk hasil dengan adanya power cylinder, dalam perhitungan perbedaan akan digunakan Spheris Equivalen (SE) dimana power cylinder dibagi 2 dan ditambah power spheris.

d. Cleaning (Pengecekan), seluruh data dimasukan kedalam program pengolah data, perlu dilakukan pengecekan kembali. Hal ini dilakukan untuk menghindari kemungkinan kesalahan kode, ketidaklengkapan dan lain sebagainya, kemudian dilakukan pembetulan atau koreksi pada data-data yang salah.

Analisia data penelitian ini menggunakan teknik analisa univariat dan analisa bivariat. Analisis univariat dengan menggunakan distribusi frekuens berfungsi untuk meringkas kumpulan dan hasil pengukuran sehingga kumpulan data berubah menjadi informasi yang berguna dan pengolahan data hanya pada satu variabel. Analisis bivariat menggunakan Wilcoxon signed rank test merupakan uji non parametrik yang digunakan untuk menganalisis 
data berpasangan karena adanya dua perlakuan yang berbeda (Pramana, 2012). Wolcoxon signed rank test digunakan apabila data tidak berdistribusi normal.

\section{HASIL DAN PEMBAHASAN}

A. Hasil

1) Karakteristik Subjek Penelitian Hasil Refraksi Subjektif Pada Jarak6 Meter dan 4 Meter Menggunakan Slide Projector

\section{Tabel 1 Karakteristik Subjek Penelitian}

\begin{tabular}{lcc}
\hline Karakteristik & F & \% \\
\hline Jenis Kelamin & & \\
Laki-laki & 17 & $32.69 \%$ \\
Perempuan & 35 & $67.31 \%$ \\
\hline Total & $\mathbf{5 2}$ & $\mathbf{1 0 0} \%$ \\
\hline Status Refraksi & & \\
Emetropia & 38 & $36.54 \%$
\end{tabular}

\begin{tabular}{lcc} 
Ametropia & 21 & $20.19 \%$ \\
Hipermetropia & 36 & $34.62 \%$ \\
Miopia Astigmat & 9 & $8,65 \%$ \\
\hline Total & $\mathbf{1 0 4}$ & $\mathbf{1 0 0} \%$ \\
\hline
\end{tabular}

Karakteristik dalam subjek penelitian ini adalah jenis kelamin dengan laki- laki berjumlah 17 orang atau $32.69 \%$ dan perempuan berjumlah 35 orang atau $67.31 \%$. Serta karakteristik status refraksi dengan 38 mata $(36.54 \%)$ emetropia dan ametropia yang terdiri dari 21 mata hipermetropia (20.19\%), 36 mata miopia (34.62\%), dan 9 mata astigmat $(8,65 \%)$ pada jarak 6 meter.

Sehingga total seluruhnya 52 orang, 104 mata.

\section{2) Analisa hasil Perbandingan Hasil Refraksi Subjektif pada jarak 6 meter dan 4 meter menggunakan slide projector}

\section{Tabel 2 Hasil Penelitian (emetropia)}

\begin{tabular}{|c|c|c|c|c|c|c|c|c|c|c|c|c|c|c|c|c|c|c|c|c|}
\hline \multirow[t]{3}{*}{ JK } & \multicolumn{2}{|c|}{$\begin{array}{l}\text { Visus } \\
\text { Dasar } \\
\end{array}$} & \multicolumn{6}{|c|}{ Hasil Koreksi 6 Meter } & \multicolumn{2}{|c|}{$\begin{array}{l}\text { Visus } \\
\text { Dasar }\end{array}$} & \multicolumn{6}{|c|}{ Hasil Koreksi 4 Meter } & \multicolumn{2}{|c|}{$\begin{array}{c}\text { Hasil } \\
\text { Perbedaan }\end{array}$} & \multicolumn{2}{|c|}{$\begin{array}{c}\text { Hasil } \\
\text { Perbedaan }\end{array}$} \\
\hline & \multirow[t]{2}{*}{$\mathbf{R}$} & \multirow[t]{2}{*}{$\mathbf{L}$} & \multicolumn{3}{|c|}{$\mathbf{R}$} & \multicolumn{3}{|c|}{$\mathbf{L}$} & \multirow[t]{2}{*}{$\mathbf{R}$} & \multirow[t]{2}{*}{$\mathbf{L}$} & \multicolumn{3}{|c|}{$\mathbf{R}$} & \multicolumn{3}{|c|}{$\mathbf{L}$} & \multirow[t]{2}{*}{$\mathrm{R}$} & \multirow[t]{2}{*}{$\mathrm{L}$} & \multirow[t]{2}{*}{$\mathrm{R}$} & \multirow[t]{2}{*}{$\mathrm{L}$} \\
\hline & & & $\mathbf{S}$ & \begin{tabular}{l|l}
$\mathbf{C}$ & $\mathbf{A}$
\end{tabular} & $\mathbf{A x}$ & $\mathbf{S}$ & $\mathbf{C}$ & $\mathbf{A x}$ & & & $\mathbf{S}$ & $\mathbf{C}$ & $\mathbf{A x}$ & $\mathbf{S}$ & $\mathbf{C}$ & $\overline{A x}$ & & & & \\
\hline $\mathrm{F}$ & 1 & 1 & - & - & - & - & - & - & 1 & 1 & +0.25 & - & - & +0.25 & - & - & 0.25 & 0.25 & 1 & 1 \\
\hline $\mathrm{M}$ & 1 & 1 & - & - & - & - & - & - & 1 & 1 & +0.25 & - & - & - & - & - & 0.25 & 0 & 1 & 0 \\
\hline $\mathrm{F}$ & 1 & 1 & - & - & - & - & - & - & 1 & 1 & +0.25 & - & - & +0.25 & - & - & 0.25 & 0.25 & 1 & 1 \\
\hline $\mathrm{F}$ & 1 & 1 & - & - & - & - & - & - & 1 & 1 & +0.5 & - & - & +0.5 & - & - & 0.5 & 0.5 & 1 & 1 \\
\hline $\mathrm{F}$ & 1 & 1 & - & - & - & - & - & - & 1 & 1 & +0.25 & - & - & +0.25 & - & - & 0.25 & 0.25 & 1 & 1 \\
\hline $\mathrm{F}$ & 1 & 1 & - & - & - & - & - & - & 1 & 1 & - & - & - & - & - & - & 0 & 0 & 0 & 0 \\
\hline $\mathrm{F}$ & 1 & 1 & - & - & - & - & - & - & 1 & 1 & +0.25 & - & - & +0.25 & - & - & 0.25 & 0.25 & 1 & 1 \\
\hline $\mathrm{F}$ & 1 & 1 & - & - & - & $=$ & - & $=$ & 1 & 1 & +0.25 & - & - & +0.25 & - & - & 0.25 & 0.25 & 1 & 1 \\
\hline $\mathrm{M}$ & 1 & 1 & - & - & - & - & - & - & 1 & 1 & +0.25 & - & - & +0.25 & - & - & 0.25 & 0.25 & 1 & 1 \\
\hline $\mathrm{M}$ & 1 & 1 & - & - & - & - & - & - & 1 & 1 & - & - & - & +0.25 & - & - & 0 & 0.25 & 0 & 1 \\
\hline $\mathrm{F}$ & 1 & 1 & $=$ & - & - & - & - & $=$ & 1 & 1 & +0.25 & - & - & +0.25 & - & - & 0.25 & 0.25 & 1 & 1 \\
\hline $\mathrm{M}$ & 1 & 1 & - & - & - & - & - & - & 1 & 1 & +0.25 & - & - & +0.25 & - & - & 0.25 & 0.25 & 1 & 1 \\
\hline$F$ & 1 & 1 & -1. & - & - & - & - & - & 1 & 1 & +0.25 & - & - & +0.25 & - & - & 0.25 & 0.25 & 1 & 1 \\
\hline $\mathrm{F}$ & 1 & 1 & - & - & - & - & - & - & 1 & 1 & +0.5 & - & - & +0.25 & - & - & 0.5 & 0.25 & 1 & 1 \\
\hline & & & & & & & & & OT & 18 & PERB & 10 & $\mathbf{A N}$ & & & & & & 12 & 12 \\
\hline
\end{tabular}


Tabel 3 Test Statistik Hasil Pemeriksaan Emetropia

\begin{tabular}{lcc}
\hline & $\begin{array}{c}\text { Hasil koreksi 4 Meter Mata Kanan - } \\
\text { Hasil Koreksi 6 Meter Mata Kanan }\end{array}$ & $\begin{array}{c}\text { Hasil Koreksi 4 Meter Mata Kiri - Hasil } \\
\text { Koreksi 6 Meter Mata Kiri }\end{array}$ \\
\hline $\mathrm{Z}$ & $-3.276^{\mathrm{a}}$ & $-3.357^{\mathrm{a}}$ \\
\hline Asymp. Sig. (2-tailed) & .001 & .001 \\
\hline
\end{tabular}

Tabel 2 menunjukkan hasil penelitian pada 52 orang atau 104 mata ditemui 14 orang (26.92\%) dengan 10 perempuan (19.23\%) dan 4 laki-laki (7.69\%) memiliki penglihatan normal (emetropia) pada jarak 6 meter. Untuk Perbandingan hasil refraksi pada jarak 6 meter dan 4 meter berdasarkan tabel 2 dari 14 orang atau 28 mata $(26.92 \%)$ terdapat 24 mata $(23.08 \%)$ mempunyai perbedaan hasil refraksi yaitu 21 mata (20.19\%) dengan perbedaan senilai $0.25 \mathrm{DS}, 3$ mata $(2.88 \%)$ dengan perbedaan senilai $0.50 \mathrm{DS}$, dan 4 mata $(3.85 \%)$ tidak ada perbedaan Dioptri. Dengan menggunakan aplikasi pengolah data SPSS 16.0 (Tabel 3) didapatkan probabilitas (Asymp.Sig) yaitu 0.01 pada mata kanan dan mata kiri.

Tabel 4 Hasil Pemeriksaan (hipermetropia)

\begin{tabular}{|c|c|c|c|c|c|c|c|c|c|c|c|c|c|c|c|c|c|c|c|c|}
\hline \multirow[t]{3}{*}{ JK } & \multicolumn{2}{|c|}{\begin{tabular}{c|} 
Visus \\
Dasar
\end{tabular}} & \multicolumn{6}{|c|}{ Hasil Koreksi 6 Meter } & \multicolumn{2}{|c|}{$\begin{array}{l}\text { Visus } \\
\text { Dasar }\end{array}$} & & & \multicolumn{4}{|c|}{$\begin{array}{l}\text { Hasil Koreksi } 4 \\
\text { Meter }\end{array}$} & \multicolumn{2}{|c|}{\begin{tabular}{|l|} 
Hasil \\
Perbedaan
\end{tabular}} & \multicolumn{2}{|c|}{$\begin{array}{l}\text { Hasil } \\
\text { Perbedaan }\end{array}$} \\
\hline & \multirow{2}{*}{$\mathbf{R}$} & \multirow{2}{*}{$\mathbf{L}$} & \multicolumn{3}{|c|}{$\overline{\mathbf{R}}$} & \multicolumn{3}{|c|}{$\bar{L}$} & \multirow{2}{*}{$\mathbf{R}$} & \multirow{2}{*}{$\mathbf{L}$} & \multicolumn{3}{|c|}{$\overline{\mathbf{R}}$} & \multicolumn{3}{|c|}{$\bar{L}$} & \multirow{2}{*}{$\mathrm{R}$} & \multirow{2}{*}{$\mathrm{L}$} & \multirow{2}{*}{$\mathrm{R}$} & \multirow{2}{*}{$\mathrm{L}$} \\
\hline & & & $S$ & $\mathrm{C}$ & $A x$ & $\mathbf{S}$ & $\mathrm{C}$ & $A x$ & & & $\mathbf{S}$ & $\mathrm{C}$ & $A x$ & $\mathbf{S}$ & $\mathrm{C}$ & $A x$ & & & & \\
\hline $\mathrm{F}$ & 1 & 1 & +0.5 & - & - & +0.5 & - & - & 1 & 1 & +0.75 & -1 & - & +0.75 & - & - & 0.25 & 0.25 & 1 & 1 \\
\hline $\mathrm{F}$ & 1 & 1 & +0.5 & - & - & +0.5 & - & - & 1 & 1 & +0.75 & - & - & +0.75 & - & - & 0.25 & 0.25 & 1 & 1 \\
\hline $\mathrm{F}$ & 1 & 1 & +0.5 & - & - & +0.5 & - & - & 1 & 1 & +0.75 & -1 & - & +0.75 & - & - & 0.25 & 0.25 & 1 & 1 \\
\hline $\mathrm{F}$ & 1 & 1 & +0.5 & - & - & +0.5 & - & - & 1 & 1 & +0.75 & -1 & - & +0.75 & - & - & 0.25 & 0.25 & 1 & 1 \\
\hline $\mathrm{M}$ & 1 & 1 & +0.5 & - & - & +0.5 & - & - & 1 & 1 & +0.75 & -1 & - & +0.75 & - & - & 0.25 & 0.25 & 1 & 1 \\
\hline $\mathrm{M}$ & 1 & 1 & - & - & - & +0.5 & - & - & 1 & 1 & +0.25 & - & - & +0.75 & - & - & 0.25 & 0.25 & 1 & 1 \\
\hline $\mathrm{F}$ & 1 & 1 & +0.5 & - & - & +0.5 & - & - & 1 & 1 & +0.75 & - & - & +0.75 & - & - & 0.25 & 0.25 & 1 & 1 \\
\hline $\mathrm{M}$ & 1 & 1 & - & - & - & +0.25 & - & - & 1 & 1 & +0.25 & - & - & +0.5 & - & - & 0.25 & 0.25 & 1 & 1 \\
\hline $\mathrm{F}$ & 1 & 1 & - & - & - & +0.25 & - & - & 1 & 1 & +0.25 & - & - & +0.5 & - & - & 0.25 & 0.25 & 1 & 1 \\
\hline $\mathrm{M}$ & 1 & 1 & +0.25 & - & - & +0.25 & - & - & 1 & 1 & +0.50 & - & - & +0.50 & - & - & 0.25 & 0.25 & 1 & 1 \\
\hline $\mathrm{M}$ & 1 & 1 & +0.5 & - & - & +0.5 & - & - & 1 & 1 & +0.75 & - & - & +0.75 & - & - & 0.25 & 0.25 & 1 & 1 \\
\hline $\mathrm{F}$ & 1 & 1 & +0.5 & - & - & +0.5 & - & - & 1 & 1 & +0.75 & - & - & +0.75 & - & - & 0.25 & 0.25 & 1 & 1 \\
\hline & & & & & & & & $\bar{A}$ & & $\overline{\mathrm{ED}}$ & $\overline{A A N}$ & & & & & & & & 12 & 12 \\
\hline
\end{tabular}


Tabel 5 Test Statistik hasil pemeriksaan Hipermetropia

\begin{tabular}{lcc}
\hline & $\begin{array}{c}\text { Hasil koreksi } 4 \text { Meter Mata Kanan - } \\
\text { Hasil Koreksi 6 Meter Mata Kanan }\end{array}$ & $\begin{array}{c}\text { Hasil Koreksi 4 Meter Mata Kiri - Hasil } \\
\text { Koreksi 6 Meter Mata Kiri }\end{array}$ \\
\hline $\mathrm{Z}$ & $-3.464^{\mathrm{a}}$ & $-3.464^{\mathrm{a}}$ \\
\hline Asymp. Sig. (2-tailed) & .001 & .001 \\
\hline
\end{tabular}

Tabel 4 menunjukkan hasil penelitian pada 52 orang atau 104 mata diketahui 7 perempuan (13.46\%) dan 5 laki-laki (9.62\%) atau 24 mata (23.08\%) dengan 21 mata (20.19\%) hipermetropia dan 3 mata $(2.88 \%)$ emetropia pada jarak 6 meter. Untuk Perbandingan hasil refraksi pada jarak 6 meter dan 4 meter .
Berdasarkan tabel 4, dari 24 mata $(23.08 \%)$ terdapat perbedaan hasil refraksi dengan perbedaan senilai 0.25DS. Dengan menggunakan aplikasi pengolah data SPSS 16.0 (Tabel 5) didapatkan probabilitas (Asymp.Sig) yaitu 0.01 pada mata kanan dan mata kiri.

\section{Tabel 6 Hasil Pemeriksaan Miopia}

\begin{tabular}{|c|c|c|c|c|c|c|c|c|c|c|c|c|c|c|c|c|c|c|c|c|}
\hline \multirow[t]{3}{*}{ JK } & \multicolumn{2}{|c|}{$\begin{array}{l}\text { Visus } \\
\text { Dasar }\end{array}$} & \multicolumn{6}{|c|}{$\begin{array}{l}\text { Hasil Koreksi } \\
6 \text { Meter }\end{array}$} & \multicolumn{2}{|c|}{$\begin{array}{l}\text { Visus } \\
\text { Dasar }\end{array}$} & \multicolumn{6}{|c|}{$\begin{array}{l}\text { Hasil Koreksi } 4 \\
\text { Meter }\end{array}$} & \multicolumn{4}{|c|}{\begin{tabular}{|c|l|} 
Hasil & Hasil \\
Perbedaan & Perbedaan \\
\end{tabular}} \\
\hline & \multirow[t]{2}{*}{$\overline{\mathbf{R}}$} & \multirow[t]{2}{*}{$\bar{L}$} & \multicolumn{3}{|c|}{$\overline{\mathbf{R}}$} & \multicolumn{3}{|c|}{$\overline{\mathrm{L}}$} & \multirow[t]{2}{*}{$\overline{\mathbf{R}}$} & \multirow[t]{2}{*}{$\bar{L}$} & \multicolumn{3}{|c|}{$\overline{\mathbf{R}}$} & \multicolumn{3}{|c|}{$\overline{\mathrm{L}}$} & \multirow[t]{2}{*}{$\bar{R}$} & \multirow[t]{2}{*}{$\overline{\mathrm{L}}$} & \multirow[t]{2}{*}{$\overline{\mathrm{R}}$} & \multirow[t]{2}{*}{$\overline{\mathrm{L}}$} \\
\hline & & & $\mathbf{S}$ & $\mathbf{C}$ & $\overline{\mathbf{A x}}$ & $\mathbf{S}$ & $\overline{\mathbf{C}}$ & $\mathbf{A}$ & & & $\mathbf{S}$ & $\mathbf{C}$ & $\mathbf{A x}$ & $\mathbf{S}$ & $\mathbf{C}$ & $\overline{\mathbf{A x}}$ & & & & \\
\hline $\bar{F}$ & $1.0^{-1}$ & $1.0^{-2}$ & -0.25 & 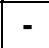 & - & -0.25 & & - & 1.0 & 1.0 & - & - & 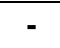 & - & - & - & 0.25 & 0.25 & 1 & 1 \\
\hline $\mathrm{M}$ & $1.0^{-2}$ & 0.8 & -0.25 & - & - & $\mathbf{- 0 . 5}$ & - & - & 1.0 & 1.0 & - & - &  & - & - & - & 0.25 & 0.5 & 1 & 1 \\
\hline $\mathrm{F}$ & 0.28 & 0.4 & -1.5 & - & - & -1 & - & - & 0.33 & 4 & -1 & - & - & -0.75 & - & - & 0.5 & 0.25 & 1 & 1 \\
\hline $\mathrm{F}$ & $.0^{-3}$ & 1.0 & -0.25 & - & - & - & - & - & 1.0 & 1.0 & - & - & - & +0.25 & - & - & 0.25 & 0.25 & 1 & 1 \\
\hline $\mathrm{F}$ & 0.8 & 1.0 & .5 & - & - & - &  & - & 1.0 & 1.0 & - & - & - & 0.25 & - & - & 0.5 & 0.25 & 1 & 1 \\
\hline $\mathrm{M}$ & $1.0^{-3}$ & $1.0^{-3}$ & -0.25 & - & - & -0.25 & - & - & 1.0 & 1.0 & - & - & - & - & - & - & 0.25 & 0.25 & 1 & 1 \\
\hline $\mathrm{M}$ & 0.8 & 0.33 & & - & - & -1.50 & . & - & 1.0 & 0.33 & - & - & - & .25 & - & - & 0.5 & 0.25 & 1 & 1 \\
\hline $\mathrm{F}$ & 0.4 & 0.4 & 00 & - & - & -1.00 & 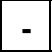 & - & 0.5 & 0.67 & -0.75 & 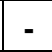 & - & -0.75 & - & - & 0.25 & 0.25 & & 1 \\
\hline $\mathrm{F}$ & 0.4 & 0.4 & -1.00 & - & - & -1.00 & - & - & \begin{tabular}{|l|}
0.5 \\
\end{tabular} & 0.67 & -0.75 & - & - & \begin{tabular}{|c|}
-0.75 \\
\end{tabular} & - & - & 0.25 & 0.25 & 1 & 1 \\
\hline $\mathrm{F}$ & 1.0 & $1.0^{-1}$ & 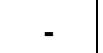 & - & - & -0.25 & - & - & 1.0 & 1.0 & - & - & - & 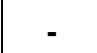 & - & - & 0 & 0.25 & & 1 \\
\hline $\mathrm{M}$ & 0.2 & 0.2 & -2.25 & - & - & -2.25 & - & - & 0.2 & 0.2 & -2 & - & - & -2 & - & - & 0.25 & 0.25 & 1 & 1 \\
\hline $\mathrm{F}$ & 0.2 & 0.2 & -2.25 & - & - & -2.25 & - & - & 0.2 & 0.2 & -2 & - & - & -2 & - & - & 0.25 & 0.25 & 1 & 1 \\
\hline $\mathrm{M}$ & $1.0^{-2}$ & 1.0 & -0.25 & - & - & - & 15 & - & 1.0 & 1.0 & - & - & - & +0.25 & - & - & 0.25 & 0.25 & 1 & 1 \\
\hline $\mathrm{F}$ & $1.0^{-2}$ & 1.0 & -0.25 & - & -1 & - & $1-$ & - & 1.0 & 1.0 & - & - & - & +0.25 & - & - & 0.25 & 0.25 & 1 & 1 \\
\hline $\mathrm{F}$ & 0.5 & 0.33 & -1 & - & - & -1.5 & - & - & \begin{tabular}{|l|} 
\\
\end{tabular} & 0.33 & -0.75 & - & - & \begin{tabular}{|l|}
-1.25 \\
\end{tabular} & - & - & 0.25 & 0.25 & 1 & 1 \\
\hline $\mathrm{F}$ & 0.8 & 0.67 & .5 & - & - & -0.75 & - & - & 0.8 & 0.8 & $\mid-0.25$ & - & - & $\mid-0.50$ & 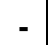 & - & 0.25 & 0.25 & 1 & 1 \\
\hline $\mathrm{M}$ & 0.4 & 0.67 & -1.25 & - & - & -0.75 & $1-1$ & - & 0.67 & 0.8 & -1.00 & - & - & $\mid-0.75$ & - & - & 0.25 & 0 & 1 & 0 \\
\hline $\mathrm{F}$ & 0.5 & 0.8 & -1 & - & - & -0.5 & - & - & \begin{tabular}{|l|} 
\\
\end{tabular} & 0.8 & -0.75 & - & - & \begin{tabular}{|c|c|}
-0.50 \\
\end{tabular} & - & - & 0.25 &  & 1 & 0 \\
\hline $\mathrm{F}$ & $1.0^{-2}$ & $1.0^{-1}$ & -0.25 & - & - & -0.25 & - & - & 1.0 & 1.0 & - & - & - & - & - & - & 0.25 & 0.25 & 1 & 1 \\
\hline
\end{tabular}


JURNAL SEHAT MASADA $\quad$ VOLUME XV $\quad$ NOMOR $1 \quad$ Januari $2021 \quad$ ISSN : 1979-2344 TOTAL PERBEDAAN 


\section{Tabel 7 Test Statistik Hasil Pemeriksaan Miopia}

\begin{tabular}{lcc}
\hline & $\begin{array}{c}\text { Hasil koreksi 4 Meter Mata Kanan - } \\
\text { Hasil Koreksi 6 Meter Mata Kanan }\end{array}$ & $\begin{array}{c}\text { Hasil Koreksi 4 Meter Mata Kiri - Hasil } \\
\text { Koreksi 6 Meter Mata Kiri }\end{array}$ \\
\hline $\mathrm{Z}$ & $-4.001^{\mathrm{a}}$ & $-4.025^{\mathrm{a}}$ \\
\hline Asymp. Sig. (2-tailed) & .000 & .000 \\
\hline
\end{tabular}

Tabel 6 menunjukkan hasil penelitian pada 52 orang atau 104 mata diketahui 13 perempuan (25.00\%) dan 6 orang laki-laki (11.53\%) atau 38 mata (36.54\%) dengan 33 mata $(31.73 \%)$ mengalami miopia dan 5 mata (4.81\%) memiliki penglihatan normal (emetropia). Untuk Perbandingan hasil refraksi pada jarak 6 meter dan 4 meter berdasarkan tabel 4.4 dari 38 mata terdapat 35 mata adanya perbedaan hasil refraksi pada jarak 6 meter dan 4 meter yaitu 4 mata
(3.85\%) miopia yang selisih perbedaan senilai $0.50 \mathrm{DS}, 4$ mata $(3.85 \%)$ emetropia dengan perbedaan $0.25 \mathrm{DS}, 27$ mata $(25.96 \%)$ miopia dengan perbedaan $0.25 \mathrm{DS}$, serta 1 mata emetropia dan 2 mata miopia (2.88\%) tidak adanya perbedaan Dioprtri pada masing-masing jarak. Dengan menggunakan aplikasi pengolah data SPSS 16.0 (tabel 7) didapatkan probabilitas (Asymp.Sig) yaitu 0.00 pada mata kanan dan mata kiri.

Tabel 8 Hasil Pemeriksaan Astigmat

\begin{tabular}{|c|c|c|c|c|c|c|c|c|c|c|c|c|c|c|c|c|c|c|c|c|}
\hline \multirow[t]{3}{*}{$\mathrm{JK}$} & \multicolumn{2}{|c|}{$\begin{array}{l}\text { Visus } \\
\text { Dasar }\end{array}$} & \multicolumn{6}{|c|}{ Hasil Koreksi 6 Meter } & \multicolumn{2}{|c|}{$\begin{array}{l}\text { Visus } \\
\text { Dasar }\end{array}$} & \multicolumn{6}{|c|}{ Hasil Koreksi 4 Meter } & \multicolumn{2}{|c|}{$\begin{array}{c}\text { Hasil } \\
\text { Perbedaan }\end{array}$} & \multicolumn{2}{|c|}{$\begin{array}{c}\text { Hasil } \\
\text { Perbedaan }\end{array}$} \\
\hline & \multirow[t]{2}{*}{$\mathrm{R}$} & \multirow[t]{2}{*}{$\mathrm{L}$} & \multicolumn{3}{|c|}{$\bar{R}$} & \multicolumn{3}{|c|}{$\overline{\mathrm{L}}$} & \multirow[t]{2}{*}{$\mathrm{R}$} & \multirow[t]{2}{*}{$\overline{\mathrm{L}}$} & \multicolumn{4}{|c|}{$\overline{\mathrm{R}}$} & \multicolumn{2}{|c|}{$\overline{\mathrm{L}}$} & \multirow[t]{2}{*}{$\mathrm{R}$} & \multirow[t]{2}{*}{$\mathrm{L}$} & \multirow[t]{2}{*}{$\mathrm{R}$} & \multirow[t]{2}{*}{$\mathrm{L}$} \\
\hline & & & $S$ & $\mathrm{C}$ & $\mathrm{Ax}$ & $S$ & $\mathrm{C}$ & $\mathrm{Ax}$ & & & $\mathrm{S}$ & $\mathrm{C}$ & $\mathrm{Ax}$ & $S$ & $\mathrm{C}$ & $\mathrm{Ax}$ & & & & \\
\hline $\mathrm{F}$ & 0.2 & 0.5 & -1.25 & - & - & -1 & -0.25 & 25 & 0.2 & 0.67 & -0.75 & - & - & -0.75 & - & - & 0.5 & 0.375 & 1 & 1 \\
\hline $\mathrm{F}$ & 0.4 & 0.67 & -0.75 & -0.50 & 90 & - & - & - & 0.5 & 0.8 & -0.75 & - & - & +0.25 & - & - & 0.25 & 0.25 & 1 & 1 \\
\hline $\mathrm{F}$ & $3 / 60$ & $3 / 60$ & -3.75 & - & - & -3.5 & -0.75 & 15 & $3 / 60$ & $3 / 60$ & -3.5 & - & - & -3.5 & - & - & 0.25 & 0.375 & 1 & 1 \\
\hline $\mathrm{F}$ & 0.8 & 1 & -0.25 & -0.50 & 65 & - & - & - & 1 & 1 & - & - & - & +0.25 & - & - & 0.5 & 0.25 & 1 & 1 \\
\hline$M$ & $2 / 60$ & $2 / 60$ & -4.75 & -0.50 & 60 & -4 & - & - & $2 / 60$ & $2 / 60$ & -4.75 & - & - & -3.75 & - & - & 0.25 & 0.25 & 1 & 1 \\
\hline $\mathrm{F}$ & 0.28 & 0.33 & -1.25 & -0.75 & 105 & -1.5 & -0.75 & 50 & 0.28 & 0.33 & -1.25 & - & - & -1.5 & - & - & 0.375 & 0.375 & 1 & 1 \\
\hline $\mathrm{M}$ & $0.8^{+2}$ & 0.8 & - & -1 & 180 & +0.25 & -1 & 180 & $1.0^{-2}$ & 0.8 & +0.25 & - & - & +0.25 & - & - & 0.25 & 0.5 & 1 & 1 \\
\hline & & & & & & & & tal & sedaa & & & & & & & & & & 7 & 7 \\
\hline
\end{tabular}

\section{Tabel 9 Test Statistik Hasil Pemeriksaan Astigmat}

\begin{tabular}{lcc}
\hline & $\begin{array}{c}\text { Hasil koreksi 4 Meter Mata Kanan - } \\
\text { Hasil Koreksi 6 Meter Mata Kanan }\end{array}$ & $\begin{array}{c}\text { Hasil Koreksi 4 Meter Mata Kiri - Hasil } \\
\text { Koreksi 6 Meter Mata Kiri }\end{array}$ \\
\hline Z & $-2.414^{\mathrm{a}}$ & $-2.530^{\mathrm{a}}$ \\
\hline Asymp. Sig. (2-tailed) & .016 & .011 \\
\hline
\end{tabular}


Tabel 8 menunjukkan hasil penelitian pada 52 orang atau 104 mata diketahui 5 perempuan (9.62\%) dan 2 laki-laki (3.85\%) atau 14 (13.46\%) mata dengan 9 mata (8.65\%) memiliki astigmat dan 3 mata (2.88\%) miopia dan 2 mata (1.92\%) emetropia pada jarak 6 meter. Untuk Perbandingan hasil refraksi pada jarak 6 meter dan 4 meter berdasarkan tabel 4.5 dari 14 mata $(13.46 \%)$ terdapat perbedaan hasil refraksi pada jarak 6 meter dan 4 meter yaitu 2 mata (1.92\%) miopia dengan perbedaan 0.25DS, 1 mata Miopia dengan perbedaan 0.50DS, 4 mata (3.85\%) Astigmat dengan perbedaan 0.37DC, 2 mata (1.92\%) astigmat dengan perbedaan $0.50 \mathrm{DC}, 3$ mata $(2.88 \%)$ Astigmat dengan perbedaan $0.25 \mathrm{DC}, 2$ mata (1.92\%) emetropia dengan perbedaan 0.25DS. Dengan menggunakan aplikasi pengolah data SPSS 16.0 (Tabel 9) didapatkan probabilitas (Asymp.Sig) yaitu 0.016 pada mata kanan dan probabilitas (Asymp.Sig) yaitu dan mata kiri.

\section{B. Pembahasan}

Karakteristik yang pertama dalam penelitian ini adalah jenis kelamin, subjek dalam penelitian ini lebih banyak perempuan sebanyak 35 orang $(67.31 \%)$ dibandingkan laki-laki 17 orang (32.69\%) diantaranya 25 perempuan dan 13 laki-laki yang memiliki kelainan refraksi pada pemelitian ini. Hal ini sesuai dengan hasil penelitiaan National Institute of Eye pada tahun 2016 yang menyatakan perempuan lebih banyak mengalami kelainan refraksi dibandingkan dengan laki-laki.

Berdasarkan status refraksi subjek penelitian yang memiliki penglihatan normal atau emetropia berjumlah 38 mata (36.54\%), 36 mata (34.62\%) miopia, 21 mata (20.19\%) hipermetropia, dan 9 mata Astigmat (8.65\%). Hal ini menunjukkan bahwa subjek penelitian yang diambil lebih banyak mempunyai tajam penglihatan yang normal atau emetropia dibandingkan ametropia seperti miopia, hipermetropia dan astigmat.

Penelitian hasil refraksi pada jarak 6 meter dan 4 meter dari 52 orang atau 104 mata secara keseluruhan memberikan hasil 97 mata memiliki perbedaan dengan pola yang sama yakni penambahan lensa plus (+) dimana mata yang emetropia pada jarak 4 meter ada penambahan plus (+) pada hasil koreksi, begitupun halnya dengan mata miopia dan hipermetropia. Untuk mata astigmat berdasarkan hasil pemeriksaan pada jarak 6 meter, ketika pemeriksaan pada jarak 4 meter diketahui tidak adanya power astigmat. Ini bisa terjadi dikarenakan power astigmat pada hasil penelitian jika di equivalent hasilnya tidak lebih dari - 0.25DS. Diuji menggunakan hasil pengolah data SPSS 16.0 menunjukkan probabilitas (Asymp.Sig) $<0,05$ pada tabel 4.2 sampai dengan 4.5 yang artinya ada perbedaan yang signifikan pada hasil penelitian perbandingan hasil refraksi subjektif pada jarak 6 meter dan 4 meter. 
JURNAL SEHAT MASADA VOLUME XV

Sehingga hipotetis pada penelitian ini dengan menggunakan aplikasi SPSS yaitu Ho ditolak dan Ha diterima karena terdapat perbedaan yang signifikan antara hasil refraksi pada jarak 6 meter dan hasil refraksi pada jarak 4 meter menggunakan slide projector.

Perbandingan hasil koreksi pada jarak 6 meter dan 4 meter dimana 83 mata memiliki selisih perbedaan $0.25 \mathrm{D}, 10$ mata memiliki selisih 0.50D, dan 4 mata memiliki perbedaan 0.37D. Menurut Hofstetter (1973) jarak pada 4 meter terdapat akomodasi sebesar $0.25 \mathrm{D}$ dikarenakan objek yang digunakan ditempatkan lebih dekat daripada infinity optik. Untuk itu, hasil penelitian yang didapatkan, diduga adanya akomodasi yang mempengaruhi hasil refraksi subjektif pada jarak 6 meter dan 4 meter.

Perbedaan hasil pemeriksaan yang dilakukan pada jarak 6 meter dan 4 meter dengan perbedaan 0.50DS ditemukan pada 3 mata emetropia pada jarak 6 meter dan menjadi S +0.50D pada jarak 4 meter, 4 mata miopia dengan koreksi S -0.50D sampai dengan $S-1.50 D$ pada 6 meter menjadi lebih ringan seolah- olah ditambahkan plus $\mathrm{S}+0.50$ pada jarak 4 meter, dan 3 mata asitgmat pada jarak 6 meter yang menjadi hilang pada jarak 4 meter. Hal ini diduga terjadi karena jarak pemeriksaan yang lebih dekat dimana akomodasi mata berperan, kurang tepatnya komunikasi dengan subjek penelitian, atau pencahayaan pada slide projector sehingga kontras pada objek terlihat lebih jelas.
4. KESIMPULAN

a. Hasil pemeriksaan refraksi subjektif pada jarak 6 meter dan 4 meter terdapat perbedaan sebesar 97 mata $(93,27 \%)$ dari 104 mata yang diperiksa dengan adanya perbedaan yang didapat rata-rata adalah $0.25 \mathrm{D}$ maksimal 0.50D

b. Hasil Pemeriksaan refraksi subjektif pada jarak 6 meter didapat hasil refraksi emetropia dan ametropia yaitu miopia dengan koreksi 0 sampai dengann -4.50D, hipermetropia dari 0 sampai dengan $+0.50 \mathrm{D}$ dan astigmat 0 sampai dengan -1.00D

c. Hasil Pemeriksaan refraksi subjektif pada jarak 4 meter didapat hasil refraksi emetropia dan ametropia yaitu miopia dengan koreksi 0 sampai dengann -4.50 D, hipermetropia dari 0 sampai dengan $+0.75 \mathrm{D}$

d. Hasil statistik menggunakan SPSS menunjukan probabilitas (Asymp.Sig) $<$ 0,05 sehingga Ho ditolak dan $\mathrm{Ha}$ diterima dengan adanya perbedaan yang signifikan antara hasil refraksi pada jarak 6 meter dan hasil refraksi pada jarak 4 meter menggunakan slide projector. 


\section{REFERENSI}

\section{Buku}

Anung Inggito, 2016, Standar Pemeriksaan Refraksi untuk Refraksionis Optisiens (diploma optometris), pp. 26-33

Notoatmodjo, S. (2012). Metodologi Penelitian Kesehatan. Jakarta: Rineka Cipta.

Rosenfield M, 2014, Optometry: Sience, Techniques and Clinical Management, Elsevier Health

Siregar, Syofian. 2013. Metode Penelitian Kuantitatif. Jakarta: PT Fajar Interpratama Mandiri.

\section{E-Book}

Andrew Keirl \& Carolina Christe, 2009, Clinical Optics and Refraction: A Guide for Optometrists, Contact Lens Opticians and Dispensing Opticians, e\%20of\%20refraction\%20examination\&f =false pp. 90-91 Tersedia [online], diakses 7 Februari 2019

Sudarwan, 2010, Riset keperawatan: Sejarah \& metodologi, ESG,

Internationally accreditest since, 2014, Kelainan Refraksi, JEC Indonesia, https://jec.co.id/id/knowledge/1/kelainanrefraksi Tersedia [online], diakses 23 Januari 2019

Harold A. Tein, Raymond M. Stein, Melvin I. Freeman, 2017, The Opthalmic Assistant E-book: A text for Allied and Associated Opthalmic Personnel, ElsevierHealth Sciences, https://books.google.co.id/books?id=VnI NDgAAQBAJ\&pg=PA114\& $\mathrm{dq}=$ Slide+projector + snellen $\& \mathrm{hl}=\mathrm{id} \& \mathrm{sa}=\mathrm{X}$ \&ved=0ahUKEwiyw5j6zqz gAhUW448KHUPrDrAQ6AEIKjAB\#v=o nepage \&q=Slide\%20projec tor\%20snellen\&f=false pp. $148-150$ Tersedia [online], diakses 10 Februari 2019

PMN RS Mata Cicendo, 2018, Pemeriksaan refraksi subjektif : duochrome test dan binocular balancing, Kementerian Kesehatan Republik Indonesia, dilihat23 Januari2019, http://www.yankes.kemkes.go.id/readpemeriksaan-refraksi-subjektif-- duochrome-test-dan-binocular- balancing4707.html Tersedia [online], diakses 23 Januari 2019

Precision Vision, 2019, Snellen Eye Test Charts Interpretation, Precision Vision, https://www.precision-vision.com/snelleneye-test-charts- interpretation/ Tersedia [online], diakses 23 Januari 2019

https://books.google.co.id/books?id=X6wxBcn xxeQC\&dq=populasi+ adalah\&hl=id\&source $=$ gbs navlinks $\_s$ Tersedia [online], diakses 20 Februari 2019

Prof. Dr. A. A Gde Muninjaya, 2016, Langkah-langkah Praktis Penyusunan Proposal dan Publikasi Ilmiah, EGC, https://books.google.co.id/books?id=HrsR 0_e8KYYC\&pg=PA24\&dq =definisi+operasional+variabel\&hl=id\&sa $=$ X\& ved $=$ PahUKEwiQtJrhlealthSciences, https://book OLgAhUIuY8KHX60BB0Q6AEIJTAA\# $\mathrm{v}=$ onepage \&q=definisi $\% 20 \mathrm{o}$ perasional $\% 20$ variabel $\& \mathrm{f}=$ false, Tersedia [online], diakses 20 Februari 2019

Suryani,2016,MetodeRisetKuantitatif,Prenada Media, https://books.google.co.id/books?id=X6w xBcnxxeQC\&dq=populasit adalah\&hl=id\&source=gbs_navlinks_s.id/ books?id=YHA-

DwAAQBAJ\&dq=total+sampling+adalah

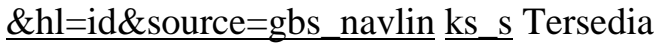
[online], diakses 20 Februari 2019

Sarmanu,2017, Dasar Metodologi Penelitian Kuantitatif Kualitatif dan Statistika, https://books.google.co.id/books?id=x0V7 DwAAQBAJ\&printsec $=$ fro ntcover\&dq=sarmanu $+2017 \& h l=e n \& s a=$ X\&ved=0ahUKEwjmLX06JPiAhXZ7XMBHRe0AoQ6AEIKDAA\#v=onepage \&q=Kerangka \%20konseptual\%20\&f=fals e,Tersedia [online],diakses20Februari,2019

\section{-Jurnal}

Wati R, 2018, Akomodasi dalam refraksi, Jurnal Kesehatan Andalas, tersedia di: http://jurnal.fk.unand.ac.id/index.php/jka/ article/download/765/621 Tersedia [online],diakses 28 Januari 2019 